\title{
THE THIRD INTELLIGIBLE TRIAD AND THE INTELLECTIVE GODS
}

\author{
EDWARD P. BUTLER
}

\begin{abstract}
Completing the systematic henadological interpretation of Proclus' Platonic Theology begun in The Intelligible Gods in the Platonic Theology of Proclus ("Méthexis" 21, 2008, pp. 131-143) and The Second Intelligible Triad and the Intelligible-Intellective Gods ("Méthexis" 23, 2010, pp. 137-157), the present article concerns the conditions of the emergence of fully mediated, diacritical multiplicity out of the polycentric henadic manifold. The product of the activity of the intellective Gods (that is, the product of the intellective activity of Gods as such), in resolving the contradiction between existential uniqueness and universalizable potencies in the divine natures, also grounds the human exercise of philosophical cognition in the founding self-analysis of divine individuals.
\end{abstract}

In two previous articles on the Platonic Theology of Proclus, I have treated of the henad in the first intelligible triad as immediately participated by Being Itself, the position of an 'intelligible God' as such; and the henad as expressing a primary manifold of powers - or a continuum of power - in the second intelligible triad and forming a primary alliance of henadic subjects in the intelligibleintellective order. ${ }^{1}$ The present article concerns the completion of the emergence of intelligibility prior to the procession of Soul; thus it concerns the henad as intelligible or paradigmatic object, and as subject/object of divine intellection.

Insofar as Proclus' account in the Platonic Theology concerns the henadic, that is, primary causal, origination of ontic determinations, understanding his account requires at each stage grasping the specific henadic activity responsible for the characteristics of the plane of being in question; thus, the present essay argues that reciprocal relation among henads is the intellective cause in general. Furthermore, however, because the ontic determinations with which this essay is concerned are intellective, it must treat as well the problem of the retrospective constitution of the philosophical system, because the latter, as a mode of reflection upon Being, is emergent from the activity of intellective Gods (or, of Gods in the intellective phase of their activity). In light of this, the integrity of the philosophical system as product of human intelligence depends upon the possibility of a rational henadology of just the sort Proclus offers, where emergent intellectual structures, while supervenient upon the nature of henadic individual- 
ity, express the intelligible conditions of the latter, and therefore are not mere contingencies of factical revelation.

The hypostatic positions treated in this essay - mixture, the third moment of the first intelligible triad; the third intelligible triad, deity as intelligible paradigm; and the intellective organization of Gods, that is, their differential or diacritical disposition - express on different planes of Being the resolution of a process that begins from the minimal difference, the root of all procession, namely the difference between a henad as unique 'existential' individual (i.e., to whom pertains hyparxis rather than ousia) and the power(s) of that individual. Proclus states as much when he says that intellective difference subsists latently and causally in the first intelligible triad, for it is «the progeny of intelligible and paternal [primary-causal] power» (PT V 37. 136). ${ }^{2}$

The powers of the Gods, Proclus affirms, are, like the Gods themselves, supra-essential (hyperousios), that is, prior to Being; that is, they are not yet formal predicates because they are inseparable from the henadic individual. Hence the mythopoetic characteristics of the Gods are neither univocal with respect to beings who possess these attributes analogically (as, say, the musicality of Apollo, which is founding for musicality as such, and the musicality of an ontic subject); nor with respect to the conceptual structures emergent from them (as the musicality of Apollo and the ontology of music); nor with respect to attributes of other Gods (as the musicality of Apollo and the musicality of, on the one hand, a God such as Hermes belonging to the same pantheon or intelligible-intellective manifold, or of a deity such as, e.g., Saraswati, who does not). The term used for such characteristics in their highest, most positive form is idiotêta; as 'powers', dunameis, they are already in transition to consideration as ontic attributes.

So too, the intelligible-intellective form of multiplicity is transitional to the properly intellective manifold. The intelligible-intellective God, the intellective God, the hypercosmic or the encosmic God is also, qua God, a member of the intelligible class (or quasi-class); but the intelligible-intellective manifold is a mode of multiplicity distinct from the intellective manifold. If the procession did not complete itself in the emergence of intellective multiplicity, if the intelligible-intellective manifold was the terminal mode of multiplicity, procession would end in a manifold constituted not by identity and difference, but by protospatial contiguity. This is the nature of intelligible-intellective multiplicity, which is not merely an abstract moment in an artificial taxonomy, but has its own genuine phenomenality. We can see from the account of the intelligible-intellective order in book IV of the Platonic Theology that this primary divine multiplicity, the first way in which the Gods are with one another, is on the one hand purely spatial and numeric, in one sense an impoverished form of collectivity, but on the other hand that this mode of multiplicity is that of the divine symposium of

${ }^{2}$ References to the Platonic Theology are to volume, chapter, page and line number in SAFFREY WESTERINK (2003). 
the Phaedrus, the pantheon, as it were, as distinct from the logical set of 'all the Gods', or all of the Gods qualified according to $x$. The intelligible-intellective manifold, if logically underdetermined, is an existentially dense henadic community, an intersubjective manifold. The logical or intellectual set, by contrast, is a class based on a common characteristic. There is thus an equivocation in the intelligible-intellective manifold traceable to the ambivalent position of Power as inseparable divine characteristic and as potential formal attribute. The intelligible-intellective manifold, native to factical theologies, is treated within the philosophical system as an intellective set, though the condition of the possibility of the latter is the activity of intellective Gods. Hence we may characterize the three intelligible triads as (1) a God simpliciter; (2) a God in a pantheon; (3) a God qualified.

\section{THE MIXED IN THE FIRST INTELLIGIBLE TRIAD}

The transition from the second to the third moment in the triadic structure of procession establishes a univocal field of Being. ${ }^{3}$ On the plane of the first intelligible triad, the most universal, it establishes mixture; on the plane of the third intelligible triad, paradigm; on the intellective plane, principle. Each of these constitute at once an existential state of the henad and an ontological grasp, or intelligence, of him/her.

Proclus distinguishes carefully between the 'exhibition' (deixis) or 'revelation' (ekphansis) of Limit and Unlimited from the God, on the one hand, and the 'production' (poiesis) of the Mixed (PT III 9.36.10-19). The two prior principles are 'exhibited' or 'revealed' by the God - any God as such - as dependent moments of his/her nature in the course of his/her activity: «The first [cause] is the God revealing the two principles; next come the two principles [themselves], namely limit and unlimited; and the mixed is fourth» (36.26-8). When Proclus speaks of these principles as inseparable aspects of the divine nature, sharing in the henad's supra-essential status, he generally refers to them as 'existence' (hyparxis), rather than 'limit', and 'power' (dynamis), rather than the 'unlimited' (or, 'infinity'), preferring to reserve the latter terms for ontological rather than henadological contexts (e.g., "limit is the limit of beings, and unlimited is the unlimited of beings» (35.1-2)). Accordingly, there are two ways of understanding the relationship between these principles and Being (that is, the Mixed as such), depending on whether we regard it from the side of the Gods, or from that of beings: «It must be admitted therefore that they [Limit and Unlimited] are un-

\footnotetext{
${ }^{3}$ On the univocity of Being, note Proclus' remarks in his commentary on the Republic that, whereas a determination such as 'generated' may be taken in a variety of senses (sêmainomena), "there is only one [property] pertaining to all intelligibles, which we call being [einai] and real being [ontôs einai]» (IR 282.13-7 Kroll).
} 
mixed and separate from Being, and that Being is at once derived from them, and consists of them. It is derived from them inasmuch as they presubsist; but it consists of them inasmuch as they come to be in it according to a secondary procession» (42.5-8). The 'secondary procession' in question is that by which, as Proclus has explained, "supra-essentials are not themselves taken into the mixture of it [Being], but these remaining transcendent, secondary processions from them coalesce [sumphyomai] into the subsistence of essence» (38.24-7). The sense of passing from a supra-essential henadic manifold to an ontic monad, is underscored by Proclus's subsequent characterization of Being as «having received a multiplicity of henads and of powers, which it has mingled into one essence» (40.7-8).

The 'mingling' or 'coalescing' of the primordial henadic manifold into a monadic and substantial unity permits the formation of a new, ontic type of manifold: Being is "a monad of multiple powers and a pluralized existence» (39.1920 ). It is not a question here of the generation of multiple henads from some abstract unity, for Being receives a primordial henadic multiplicity. Rather, it is a question of the pluralization occurring within each 'existential' henadic individual, in particular the differentiation of that individual's powers or attributes, which are potential universalities, from the hyparxis itself which, as the very uniqueness of the henad, will resist ontological appropriation. This is the tension that I have identified as the engine of the procession of Being in Proclus: the expression of potencies by the henads creates a monadic center which is at once the diremption of each henad and a common space for the henadic collective. All intellection is reversion, epistrophe, and reversion is inseparable from the henad's self-alienation in Being: «How can there be reversion without distinction [diakrithen] (since all reversion seems to be the resolution of something into that from which its being divides it)?» (ET prop. 35). ${ }^{4}$ Unlike beings, the henads introduce this division into themselves through the expression of relations among one another, which is the very production of Being. Hence this monad, Being Itself, is at once the pluralization of each God and the unification of the Gods as a class: thus the Mixed is «the first and highest diakosmos of the Gods» (45.6-7), that is, the most universal classification of them. At the same time, it is not merely a matter of classification, but also of a state of the henad him/herself. Each henad passes within him/herself from the state of positive, existential individuality to that of negative, diacritical particularity, from the state of primordial uniqueness to that of the sole member of his/her species. This is the most universal understanding of a God's activity in general, and accordingly the transition to Being does not take place solely in the first intelligible triad, but on each and every plane of Being.

\footnotetext{
${ }^{4}$ References to the Elements of Theology are by numbered proposition in DODDS (1963).
} 


\section{THE THIRD INTELLIGIBLE TRIAD: HENAD AS PARADIGM}

The third intelligible triad is "an intellective God in the primary sense» (prôtôs; PT III 14. 51.9-11). Each of the triads is, we may say, expressive of what it is to be $a \mathrm{God}$; the third triad, specifically, of what it is to be an intellective God. To be an intellective God is a matter of a specific divine activity: it is to be a God cognizing.

The essence of the intellective disposition for Proclus is a triadic disposition of the henad relative to self or other. The third intelligible triad, Proclus explains, "constitutes intelligible intellect in relation to itself [peri heautên] and fills it with divine unity, making power subsist as the medium between itself and being, through which it fulfills this being and converts it to itself» (PT III 14. 49.15-18). The intellect is thus a product of the henad to which the henad is related, and this affects the relation between the henad and its power(s). The second intelligible triad already «revealed secondary being», that is, intelligible-intellective being or Life, "from itself and in relation to itself [peri heauton]» (PT III 12. 46.21-2). But where Life, like the power(s) from which it springs, is a 'revelation', Intellect is a product, and it brings all the prior moments of the procession into concretion as products themselves. Thus Proclus explains that the third intelligible triad is «the Limit [peras] of all the intelligibles» (14. 49.23-4), where it is clear from the context that he does not merely mean «limite inférieure», per Saffrey and Westerink. Rather, intelligible objects qua intelligible acquire their own limit, that is, the existence appropriate to them, in and through the intelligible intellect, which expresses relations among henads in an objective form.

For the henads as such are without relation: ET prop. 122 explains that «relation [schesis] is a qualification of being, and therefore contrary to its [the henad's] nature». The procession of Being, however, is precisely the emergence of relation from out of primordial henadic autarchy. Thus, Proclus explains that the first intelligible triad is treated in the Parmenides as «the One, Being, and the relation [schesis] between the two" (PT III 24. 85.17-8). Proclus preserves the henads from relation by construing the relation one would posit between any two henads not as one thing, but as two, namely, a power in each henad productive of the relation (IP $1190,936,942){ }^{5}$ The powers of the Gods thus remain really inseparable from their divine individuality, while Being is an emergent third in the dyadic relations among henads and in each henad's self-relation. Indeed, the fact of this emergent thirdness, a formal unity - 'unified', hênomenos, as opposed to 'unitary', heniaios - is more significant than whether it emerges from the dialectic within henadic individuals or between them, since it must ultimately be understood in any case as both the henad cognizing him/herself and the henads cognizing one another.

\footnotetext{
${ }^{5}$ References to the Parmenides commentary are to the page numbers in the Greek text, translated in MORROW - RILLON (1987).
} 
The first site for this dialectic is the relationship between the demiurge and the paradigm (the third intelligible triad or 'Animal Itself'). In dealing with the problem of the union or separateness of demiurge and paradigm, a problem with historical depth in the Platonic schools, Proclus emphasizes the asymmetry between them, as he will later emphasize the symmetry in the relations between the intellective Gods. "Animal Itself [to autozôion]», he explains, "comprehends [perielepphen] the Zeusian series in itself intelligibly, while as demiurge of the All, Zeus intellectively preestablishes in himself the nature of the Living [tên tou zôiou physin]» (PT V 27. 100.2-5). Perilambanô, to comprehend, pertains typically to powers in whole-and-part relationships (e.g., ET prop. 60), a relation originating among the divinities (prop. 150) and passed on to ontic principles, so that, e.g., Being and Life are in this relationship (prop. 105), as are divine and ontic principles in a certain respect (prop. 143); but between the divine and the ontic realms, the relation is also in a different respect absolute, so that a divine power can be said categorically to be uncircumscribed and comprehend everything (prop. 121). The hierarchical relationships between deities are just such relations, which concern the expression of powers in causal activity. With respect to the three moments of the divine nature, existence (hyparxis), power (dunamis) and intellect (nous), the henads are existentially equal; dynamically they are in a host of essentially dyadic relationships of comprehension; and the characteristically intellective relationship is that in which Zeus preestablishes the nature of Animality in himself - 'comprehending' through the idea.

The third intelligible triad is «the first cause of production and demiurgy» (PT III 19 67.12-3). Concretely, Animal Itself is 'holistically' (holikôs) constitutive of living beings (53.14) through embracing the four fields or zones of divine activity that ground the equivocal sense of 'animality' as applying to divine, angelic, daimonic and mortal animals respectively, and which arises from the different possible formal relations between the One and Being, that is, between each God and his/her production, in which the One (the God) is «absorbed by Being» and vice versa (PT III 27.97.16ff). The demiurgy of the third intelligible triad, that is, of an intellective God as such, is a relation to objectivity. It has as its precondition that the One and Being are treated as distinct monads; the resulting vertical multiplicity, though, while expressing the objectivation of Being as a moment of the God, still occurs within each God; any relation between Gods is still implicit on this plane. Hence the God as intelligible animal in general is «one of a kind» (monogenes), while the demiurge's specific animality «produces itself among beings ... together with the zoogonic cause, with which it constitutes secondary entities, mixing the genera of Being in the krater for the sake of the generation of souls», (PT III 15. 53.15-18). The principal form of this cooperation in the intellective and subsequent divine orders is the emergence of familial relationships within the pantheon. The point of the zoogonic causality operated by feminine divinities is not birth - viz. the zoogonic korai, 'maidens', in the hypercosmic orders (PT VI 11) - but the expression of relations among Gods 
preexisting «themselves for themselves» (IP 936), these very relations generating the psychical plane of Being.

Qua paradigm, therefore, the intellective deity as such is relatively passive with respect to its intellective enactment. The demiurge sees the paradigm, as do our own souls (IT I 323), ${ }^{6}$ for it is "the most beautiful of intelligible objects» (Tim. 30d1-2), divine beauty as such, the beauty specific to every God qua God. It is that animal of which all other animals, divine and mortal alike, are parts insofar as they are intelligible objects, and hence we see it in each animal insofar as we see the totality, the All in it, the intelligible totality of the cosmos which is secured through each animal's own integrity - the sense, that is, in which each animal is not an accident of the cosmos but an organic part of it. The Orphic Phanes, in contrast to the demiurge, "cherishes in his heart fleet, eyeless love» for the cosmos (IT II 85; III 101) for this God «neither requires eyes in order to see, nor ears in order to hear" (IT II 85). Note as well that Phanes' love for the cosmos is 'fleet', ôkys, ephemeral as lacking temporal extension, for temporality is inseparable from intellective formation. The demiurge interposes a relation between himself and the paradigm, so that one God 'sees' the cosmos in another: "Plato asserts that the demiurge looks to the paradigm, indicating through sight intellectual perception [noêsis]» (IT I 324). With this noesis, a diremption of the primordial presence of all the Gods to each that characterizes the henadic manifold, come determinations definitive of intellective being, and which characterize the triangular relationship between demiurge, paradigm, and cosmos. Thus the demiurge desires that the processual totality should approximate himself (panta ... paraplesia) (Tim. 29e), while the cosmos bears likeness (homoiotês) to the paradigm (Tim. 30c); the cosmos is «an image [eikôn] of the paradigm and a product [apotelesma] of the demiurge» ( $P T$ V 29 108.9-10).

Insofar as all the henads are in each, the demiurge may be said to contain the paradigm as much as the paradigm may be said to contain the demiurge. This is true of any two Gods, but the mediation between paradigm and demiurge founds intellective being as such. "In some places Plato says that the demiurge is the same [tauton], and in others that he is different [heteron] from the paradigm, and each of these appropriately" (IT I 324); note the use of the explicitly intellective language of identity and difference. In addition to the mutual inclusion of demiurge and paradigm in each other, there is also a hierarchical relationship between them, or rather, two such relationships. Proclus discusses the reasons why we may regard now the one, now the other, as prior: the demiurge is referred to by Timaeus as «the best of causes» because Timaeus considers the third triad «according to its formal nature [eidetikên physin] and not according to the unity [henôsin] in it and an hypostasis beyond the forms of the All» (PTV 29 107. 1114). According to «the henads in them», however, the paradigm is intelligible, the demiurge intellective, and the former hyparxis is closer to the One (107. 19-

\footnotetext{
${ }^{6}$ References to the Timaeus commentary are to volume and page in DIEHL (1903-6).
} 
23). The demiurge is treated as the agent in Timaeus' account, the paradigm formally; in the Orphic theogony, by contrast, Phanes, in the position of the paradigm in the merely formal account, has his own agency prior to that of Zeus. The theogony is not a genesis of Gods, but an order of the deployment of causality: «The demiurge is contained [periechetai] by the intelligible animal according to the order of causation [kata ton tês aitias logon], and not as a part, and thus imperfect» (IT I 433). To be «closer to» or «further from» the One is a metric of the breadth of causation; the One is not a third relative to two henads. Proclus distinguishes formal and causal modes of containment (perioches), "the one being such as that of parts in their wholeness", i.e., formal, "the other that of effects in their causes» (IT I 432). Hence the way a divine intellect 'contains' forms differs from the way it 'contains' partial intellects, e.g., subsequent divine processions in an intellective causal series. Each of the more 'partial' divine intellects «is all things in a self-perfect [autotelôs; cf. ET props. 64, 153] manner», while each of the forms «is united to other forms, but is not all things. For each [of the partial divine intellects] is itself preserving its own individuality [idiotês] unmingled and unconfused» (IT I 432.8-11) ${ }^{7}$ An example would be the relationship of the Olympian children of Zeus to their 'father': as intellective causes, they presuppose Zeus' wider activity, while qua Gods, each is an individual comprising all things.

In the passage from the Timaeus commentary, Proclus offers specialized terminology for dealing with the way in which some henads are said to be 'prior' to others, terminology which depends on the determination of 'totality' (to pan) essential to the third intelligible triad: "All such things, therefore, as are in the paradigm are likewise in the demiurge; and in making the cosmos with reference to the paradigm, he also makes it with reference to himself. With respect to allness [pantotês], however, one is intelligible, the other intellective ... so that the demiurge, possessing all such as intelligible animal possesses, yet has an allness subordinate to that which is intelligible» (IT I 432.16-25). Totality is specific to the third intelligible triad as Wholeness was to the second. The priority of Wholeness lies in its ability to determine Totality as a unit: "The all is a whole, but the whole is not necessarily all ... whole is the coherence [synochê] and integrity [henôsis] of the all» (PT III 20. 72.13-19). If we are to accord a proper sense to the term 'totality', the subordinate totality must somehow be the same totality as the superior one, and yet also really subordinate in its unit-character.

No henad preexists another. But the activity of one may presuppose that of another, as in the case of a deity who posits another as his/her 'parent'. An 'offspring' among the henads «exists 'for itself', and only then derives from some-

\footnotetext{
${ }^{7}$ The wording here closely parallels the contrast Proclus draws at IP 1048 between the different manners in which forms, on the one hand, and henads, on the other, are 'all in all', for "the individuality [idiotês] of each of them [the henads] is a much more perfect thing than the otherness of the Forms, preserving as it does unmixed all the divine entities and their proper powers distinct»; and again, at 1049 Proclus speaks of the «unmixed distinctness of the primal, supra-essential henads».
} 
thing else» (IP 936). The effect of the henad's positing his/her derivation is expressed in the totality dependent upon him/her. Each henad is absolute and autarchic, but one subordinates him/herself to another in the exercise of certain powers, «as for instance in the demiurgic classes Zeus directs now Athena and now Apollo, and then again Hermes, and Iris; and all these obey the wishes of their father ... according to the demiurgic norm [horon] directing their own providential wills towards the entities secondary to them» (IP 940f). This subordination is founded in the relationship between demiurge and paradigm, which is also 'paradigmatic' for all paradigmatic relations among beings.

\section{THE ACTIVITY OF THE INTELLECTIVE GODS: DIAKRISIS}

In the Philebus (23d), Socrates entertains the notion that a fifth principle of Being shall be required in addition to Limit, the Unlimited, the Cause of mixture, and Mixture itself, namely diakrisis, the differential principle. Socrates defers consideration of this principle. In treating what we may call radical Being, Being Itself, there is not yet ground to distinguish between a being's 'mixed' character and its position in a differential organization of Being. We take up diakrisis once we have detached Being as product from its producer, the henad as cause, inasmuch as in the purely differential system of being there is only relational, negative identity, and no place for the henad's primordial positivity. But there is no Being without henadic activity; and so this activity must adopt a different form to generate diacritical being. This is reflected in the structure of the intellective order, which no longer presents itself as nested triads, like the intelligible and intelligible-intellective classes, but as an integral hebdomad, a structural difference conveying immediately that the collective product of the intellective Gods can no longer be deduced from the simple determinations of henadic individuality.

The primary source of the hebdomadic structure in the intellective order is the guardian or protective function emerging there, effectively a fourth moment in the dialectical pattern of emergence whose structure in the pre-intellective organization was rigidly triadic. This fourth moment, attaching to each person of the paternal - i.e., primary-causal (prôtourgon, ET prop. 151; note also the gloss of «paternal» as pertaining to a God's «existence proper» at $P T$ V 39. 144.18-9) - triad in the intellective order, results in a hexad, to which a special diacritical monad is added, resulting in the hebdomad. Aside from the identification with the Kouretes in the intellective ( $P T \vee 35)$ and Korybantes in the hypercosmic orders ( $P T$ VI 13), the guardian function is presented more often as discrete 'monads', i.e., aspects or relations, of the intellective 'fathers' themselves, as elements, that is, of their activity. This is true as well in the hypercosmic orders, insofar as the function is partly absorbed into important 'virgin' Goddesses active on that plane (previewed in the special role accorded to Athena in relation to 
the guardian class at $P T \mathrm{~V} 35.128 \mathrm{ff}$.). The diacritical monad, for its part, is a perfectly impersonal monadic position in the system, underscored by its systematic determination as difference-from-self ( $P T \mathrm{~V}$ 40. 148.6-7): it represents the accomplishment of the differential organization of the field of revelation, which has, just in becoming differential, become not just ontic, but nascently ontological.

The primary divine causality, the moments of positive divine activity, in the intellective order is therefore outnumbered in its moments, four to three, by moments we might characterize as a secondary or reflective divine causality. This is in accord with the essentially negative, differential or diacritical nature of intellective being. The guardian potency - or 'protective', 'immaculate', 'inflexible', et al, the terminology for this order being unusually diverse - maintains the hierarchical disposition existing, in particular, between the intellective and psychical organizations, where Becoming constitutes itself in the relation of likeness to determinate, Intellective Being. Its most overt function, therefore, may be characterized as anti-psychologistic, inasmuch as it prevents the intellective collapsing into the psychical (it is thus easy to see why this function is even more prominent in the divine orders which carry out the procession of Soul itself). ${ }^{8}$

More broadly, the positivity of the guardian moment lies in conserving the positivity of the product of the unfolding dialectic of henadic individuality at each stage. This function is inseparable from the determinacy of dialectic itself. The roots of dialectic lie in the emergence among the Gods of mythic narrative, and it is such narrative itself which is embodied in the seventh or diacritical monad insofar as it is not a divine person, a henad, but instead a conjunction of persons in action. The intellective and infra-intellective orders of Gods are deeply involved in complex mythic narratives. Indeed, the density of narrative interconnections seems to define an intellective God, and the practice of mythological hermeneutics results, generally speaking, in articulating the intellective plane of Being. ${ }^{9}$ The primordial intelligible organization, by contrast, emerges not from reflection on narratives, but from the elemental analytic of henadic existence.

The seventh or diacritical monad of the intellective order separates in particular the sovereignties exercised by Ouranos, Kronos and Zeus in the Hellenic field of revelation ( $P T$ V 36. 132f). Each of these sovereignties is intellective in its own right, but the diacritical monad «separates the Kronian genera from the

\footnotetext{
${ }^{8}$ Psyche's division from intellect can be discemed in the guardian order's regulation of motion: thus the Kouretes are «the principal paradigms of all graceful motion» (V 35 128.9-10). Here intellect acts upon (psychical) motion, intellect and psyche being thus affirmed in their distinction. The ideal motion that founds the self-motion of psychical being, and hence the higher indivision of intellect and psyche, subsists on the intelligible-intellective plane; note in this regard that the "guardian good ... extends from the connective [i.e., intelligible-intellective] Gods to the intellective kings) (V 34. 125.27f).

${ }^{9}$ On mythological hermeneutics, see BUTLER (2005).
} 
Ouranian, and the Zeusian from the Kronian, distinguishes the whole intellective organization from those prior and posterior to it, detaches the different causes in it from each other and always imparts secondary measures of sovereignty to secondary things» (V 3. 17.16-21). The means by which this separation occurs is the very mythic narrative of divine succession itself. The motif of 'sections' or 'cuts', tomai, in these narratives, stressed by Proclus but present in the tradition primarily in Hesiod's account of the revolt of Kronos against Ouranos, ${ }^{10}$ is symbolic in itself, but is also a synecdoche for the 'cuts' created by the narrative form itself; thus «the myth in the Gorgias (523a) ... detaches the realm [archên] of Zeus from the Kronian sovereignty, and it calls this realm secondary to that one and younger [neôteran]» (V 36.132.16-19), though there are no literal 'cuts' in this narrative; the 'cut' in question is the diachrony introduced by narrative itself into the eternal divine nature.

The peculiar importance of the 'cut' inflicted upon Ouranos in Hesiod's narrative lies as well in the cut or separation such narratives perform between those, like Euthyphro, who grasp only "the appearance itself» with regard to the «unlawful acts» in the myths, and those able to penetrate into their "mystical truth» and "concealed meaning" (V 3.18.9-16). This hermeneutical 'cut' between the exoteric and esoteric within a sacred discourse - theomythia, 'divine myth' - is itself ontological. We may compare it to the division introduced within the procession of the intellective Gods by the demiurge's address at Timaeus $42 \mathrm{~d}$ to the «young Gods» (neoi theoi), discussed by Proclus at IT 3,310f, in which it is the demiurgy of the apparent by the "young Gods» that characterizes their activity as «youthful» in contrast to the "ancient and venerable nature of the unmanifest [aphanous] demiurgy" (IT 3, 310.10-11) carried out by the 'senior' generation of intellective Gods. The 'young' Gods are youthful «not as beginning to exist sometime», but insofar as "bodies in process depend upon them, and these are not allotted existence eternally, but according to a whole <unit> of time» (IT 3, 311.7-10).

Hierarchical displacements of divine activity relative to one another can only occur on the common field of Being. Thus, by virtue of the diacritical monad «Zeus separates himself from the monad of his father, Kronos from the kingdom of Ouranos, and those secondary to Zeus, proceeding into a subordinate class, are separated from his perfect providence) ( $P T \mathrm{~V}$ 36. 132.23-27). In each case it is not persons who are separated, but products: an ontic position, a field of activity, a providential cognition (pro-noia). Narrativity is thus merely one dimension of the relational, differential Being produced within this order on the basis of the potential inherent in the henad as such, and which is embodied in the third intelligible triad. In the address to the "younger Gods», the demiurge, who objectivized a relationship with the paradigm through his noêsis, now institutes through

\footnotetext{
${ }^{10}$ Orphic frag. 154 (Porphyry, De antro nymph. 16 p. 67 Nauck) refers as well to a castration of Kronos in the manner of Ouranos.
} 
his logoi a common work among its divine recipients: "The result of his words is to render demiurgic the Gods receiving them ... each [of the encosmic Gods] partakes of the demiurgic [characteristic, idiotês] insofar as $\mathrm{s} /$ he is coordinated with the demiurgic monad ... If the speaker was a zoogonic God, we would say that $\mathrm{s}$ /he filled the hearers with divine life through her words; but since the demiurge is the orator, he imparts to the Gods the demiurgic characteristic, distributes his singular demiurgy among the manifold of encosmic Gods, and displays them as demiurges..." (IT 3, 198.9-199.7).

Proclus reminds us that the encosmic Gods who receive the demiurge's address, despite their diverse classifications - «demiurgic, zoogonic, connective, perfective, guardian, judicial, cathartic» - «nevertheless all partake of all powers" (198.25-9); that is, they are all henads and thus enjoy the basic henadic attribute of all-in-each. Therefore, the effect of the address of logoi from one God to another is to produce through discourse a univocal field that at once binds God to God, and divides them. Between demiurge and paradigm it was a pure noêsis; here it is a logos. ${ }^{11}$ Proclus stresses the unity of the demiurge's discourse at IT 3,202, when he states that «How those to whom the cosmos is allotted by the father are called 'Gods of Gods' (Tim. 41a) and according to what concept is not easy to indicate to the many, for there is the revelation of a singular divine intelligence ${ }^{12}$ in these expressions». The demiurge's address is not immediately reducible to conceptual terms because it is first-person speech, hence sharing the nature of henadic individuality; but this direct address of a factical individual to a determinate (if unspecified) audience of others establishes the conceptual space of demiurgy.

Henadic mediation becomes concrete in the intellective order in the relationship between the first and third intellective 'fathers', e.g., Kronos and Zeus, in their reciprocal 'binding' of one another. Drawing upon unknown source material, Plato had already spoken of «the famous bonds of Kronos» (Crat. 404a), referring to Kronos as binding others. In the account of the procession of the intellective Gods, however, Proclus refers chiefly to Kronos' being bound by Zeus. ${ }^{13}$ The binding of Kronos by Zeus is in any case reciprocal for reasons philosophical rather than mythological: «in binding [desmein] his father, he [Zeus] at the same time binds himself [to him], for a bond is the comprehension [perileppsis] of the things that are bound» ( $P T$ V 5. 21. 15-7). Zeus binds Kronos by

${ }^{11}$ In the mediating position, we may note, is the establishment of the forms of law (nomos) and institution (thesmos) through the activity of the intelligible-intellective Gods (PT IV 17. 51-3), which is also the precondition for the acts within the succession myth to be characterized as "unlawful".

${ }^{12}$ Accepting the emendation of mias for aidias at 1.27 .

${ }^{13}$ There is a brief reference to the binding of the Titans by the Olympians in Hesiod (Theog. 718), but Proclus appears to be drawing upon Orphic traditions; Orphic frag. 154 (Porphyry, De antro nymphar. 16 p. 67 Nauck) refers to a binding of Kronos by Zeus. 
«holding Kronos in himself in a Zeusian mode» (IC 89.15-6). ${ }^{14}$ Proclus uses this terminology for the inherence of all the henads in each one: Kronos is in Zeus 'zeusically', Zeus is in Hera 'heraically' and so forth. ${ }^{15}$ This particular instance is special, however, in that it is rendered thematic in divine cognition, so that the bond itself becomes objective as a comprehension or perilepsis, a term familiar from the intelligible-intellective plane. The bond between Kronos and Zeus thus becomes a connecting and containing ideal space. Henads precede their relations; hence the relationship between Kronos and Zeus is in the first place a power in Kronos of being-in-relation-to-Zeus, and a power in Zeus of being-inrelation-to-Kronos. In the emergence of intellective being, however, the relation is thought in its objectivity, and so becomes objective. Zeus «has turned back to Kronos, is dependent upon him, contemplates the lengths and widths of the Kronian 'observatory', and situates Kronos in himself ... So Zeus binds Kronos in himself firmly and permanently, and Zeus is bound to Kronos in like manner»" (IC 89.13-18). Zeus makes Kronos' viewpoint, his periopê, intellectively accessible, and himself becomes cognizable as well. «Kronos is an all-perfect intellect, and the mighty Zeus is likewise an intellect. Each therefore being an intellect, each is also evidently an intelligible» ( $P T$ V 5.21. 18-20) - as intelligent agents or subjects, Zeus and Kronos are also objects of intellect, reciprocally binding each other as objects of understanding. In deities becoming objective to one another, therefore, Intellect itself subsists as a distinct plane of Being, which must be in some way separate from the Gods insofar as beings derive their forms from it, and this process of formation is not wholly reducible to divine participation - if it were, we would have no means for understanding beyond revealed theology. The binding of each other by intellective Gods such as Kronos and Zeus, therefore, is essential to the relative autonomy of Intellect, that is, of the realm of Form. Being, as the common space of the Gods, comes from the Gods' self-reflection as well as their otherness-to-self, with which comes their otherness to one another. This occurs in stages: Phanês shines forth as manifestation or appearance itself, while Ouranos establishes primary place, topos, from which nothing would be separable, but for Kronos dividing intelligence from the scene or event of intellection (noêsis). Kronos binds others intellectively, returning all else to himself, but in Zeus, the third intellective 'father', the intellection itself achieves determinacy. Thus Proclus quotes the Platonist Amelius as referring to three demiurgies and sovereignties, one that is (Phanês), one that has (Kronos), and one that sees (Zeus) (IT I 306, III 103, interpreting Tim. 39e7-9), to which Proclus adds that we should understand Kronos as both being and having the intelligible and Zeus as being, having and seeing it ( $P T$ V 5. 23). Demiurgy simply is this effective seeing: seeing the forms of life with which the paradigm is

\footnotetext{
${ }^{14}$ References to the Cratylus commentary are to page numbers in PASQUALI (1908); trans. DUVICK (2007).

${ }^{15}$ I have discussed this phenomenon particularly in BUTLER (2008).
} 
replete, the demiurge creates Soul as the vehicle for a manifold of beings to manifest themselves to one another.

The activity of the first intellective father - and we must always bear in mind that 'father' is a technical term in Proclus, not an anthropomorphism - is expressed in the determinations of in self and in other from the Parmenides. That neither of these apply directly to henadic individuality can be seen from the fact that in other applies to the first father, while in self applies properly to the guardian monad attached to him. That is, the primary activity of the first intellective father is to project himself into the intelligible Other, returning it to himself in his secondary activity: "For he is in himself and in another. Insofar as he is a whole intellect, he acts toward himself, but insofar as he is in the intelligibles prior to himself, he establishes in another the all-perfect intellection of himself») ( $P T$ V 37. 135.17-21). The 'priority' of the intelligible to the first intellective father here is purely relative to his action; as Proclus reminds his readers a few pages later (141.25-7), one is never «attributing to the Gods elements of Being, but properties [idiotetas] appropriate to them which are all-perfect and superior to beings».

All Gods are supra-essential henads, no matter on what plane of Being they cast their activity. The intelligible koinon is inferior to the henadic individuals, wherever they may operate in the hierarchical organization, and so the highest intelligible is actually inferior to the 'lowest' of the Gods. Only by appreciating this fact may we properly grasp the significance of the first intellective father's self-projection into the intelligible, which makes possible the third intellective father's demiurgy. The demiurge organizes the cosmos according to a vision of the paradigm, that is, a vision of the intelligibility of another God or of himself qua other. In this operation, otherness (allotês) gives birth to difference (heterotês). "The Other is present cryptically and causally in those [the intelligible triads] ... The in-another adheres to the difference associated with unitary number; but unitary number is suspended from the latent union of the One Being, on account of which also it is unitary» ( $P T$ V 37. 136.12-19). 'Unitary number' (heniaios arithmos) is henadic multiplicity, the analogue on a higher plane of our 'numerical difference'. The otherness of henads to one another precedes difference as such, which is unthinkable without reciprocal identity. Proclus discusses the relations among these terms in an important technical discussion, in which the otherness of henads is distinguished from the difference of forms, for the latter is a "reciprocal otherness»: «[1]n the supra-essential realm, ... in place of the distinction [diakrisis] of coordinates from each other [we must postulate] individual peculiarity [idiotês]» (IP 1190.30f).

«This Other», Proclus writes, speaking of the alterity into which the first intellective father has projected himself, "pertains to that order according to which the power of difference is first manifest, as the offspring of intelligible and paternal power. Hence the Other was in the first [intelligible] triad latently, inasmuch as power was there» ( $P T$ V 37. 136.1-4). The first intelligible triad is the 
most universal expression of a God as active in the constitution of Being; its product is Being Itself. Each God, thus, is the first intelligible triad; but all the Gods are in each. In the first intelligible triad, the other Gods, who are the Other as such, each God being a primordial Self, are cryptically or latently (kryphios) present - which is as much as to say, present without mediation - as the continuum of power (dynamis) in the henadic person. The primary sense of power in the first intelligible triad is the manifold of attributes or qualities in the God which are the locus of universality in him/her. However, inasmuch as this is the first difference, namely that between the unique henadic individual and his/her properties - it also contains in latent fashion the potential relations between each God and any or all other Gods; the henad, as supra-essential, is «non-relational, though productive of a relation» (IP 936). In the intellective order this latent aspect of the henad becomes manifest, and henads are posited in relation to one another.

In the first stage of the process, the first intellective father, Hellenic Kronos, manifests other Gods as offspring, then reabsorbs them. "The first intellective father is 'father' through himself, but on account of the immaculate [monad], he contains [periechei] in himself the classes [genê] of himself, recalls them fixedly to himself, and in his own selfhood [heautotêti] ${ }^{16}$ encompasses [synechei] the intelligible multiplicities of the intellectives inseparable from his own monad" (PT V 37. 138.1-6). The «immaculate» (achrantos) or guardian monad functions here as an aspect of the henad's activity, the aspect of being-in-self. The Others are present as an intelligible continuum; note the use of terms such as periechein and synechein, which evoke the intelligible-intellective plane, as above we read that «the Other is latently and causally present in the intelligible of intelligibles [first intelligible triad], but essentially in the intelligible of the intelligibleintellective Gods» (136.12). But They are inseparable from his own intelligibility, his monadic or ontic identity. Thus his intelligence is 'pure' (Kronos as koros nous, pure intellect). The guardian monad here is the first intellective father's resolution of the alterity present in him - the other Gods as well as his own content, properties, or attributes - into one common intelligible objectivity. A key expression Proclus uses for this activity in the first intellective father is to speak of the latter's "wholeness", holotês. Henads are prior to wholeness; mereology is constitutive of ontology as science of beings (ET props. 66-74). Accordingly, the first intellective father «is established in another insofar as he is [a] whole ... The parts of this wholeness are particular powers striving to proceed from the father, but established in and contained on all sides by it [the wholeness]. And this wholeness is itself a godhead [theotês] connecting [synektikê] the intelligible parts in itself») (138.14-22). Kronos encompasses his children intellectively; but this relation, as a mythic event, is itself a divinity of sorts, acquiring autonomy through the diacritical monad, or difference-from-self.

\footnotetext{
${ }^{16}$ Rejecting the unnecessary, though plausible, emendation to pantotêti, 'allness', at 138.4.
} 
Indeed, each of the intellective fathers in some way experiences differencefrom-self. The first intellective father thinks himself; the second intellective father, Hellenic Rhea, moves herself; the third intellective father, Hellenic Zeus, relates to himself. Just as the first intellective father, through the determinations of being in other and being in self projects himself into the intelligible «viewpoint» (periôpê) as a wholeness, so the second intellective father «is filled from transcendant Life» - that is, the second hypostasis - and so «is at once motion and that which is moved" (140.26-7). She is "the mover of wholes and first moved from herself» (142.9-10). The primary motion is ideal genesis; for as Proclus explains, while «that which is generated simpliciter receives essence, power and activity according to time, that which is in a sense generated» - ideal genesis - «possesses activity in motion and duration» (IT I, 277). In an even broader sense of 'generation', however, "everything proceeding from a cause is called generated» $(I T \mathrm{I}, 280)$ and with respect to the Gods specifically «though we sometimes speak of generations of the Gods, we say this indicating their ineffable procession, the difference of the secondary relative to their causes ... for them, procession and generation are the same» (280.19-28). Procession is strictly speaking acausal for the henads, inasmuch as the One is not a cause; to be caused in general thus is a relation to the divine in general, while to be generated in any sense is to be posited in relation to a certain cause (IT I, 298.11-17). In this way, generation among the Gods elaborates the basic intellective theme of diakrisis or determinacy. In the intellective organization Gods come to be caused in the particularity of relations to one another, a prerequisite for the articulated condition of beings. As self-constituted (authypostatos), the henad «though you may conceptually divide it into cause and caused ... proceeds from its own being» (IT I, 281.6-10); but the procession is real, the uncaused Gods appropriating to themselves genuine relations of origin and locality.

The second intellective father is responsible therefore for beings qua beings, from the highest to the lowest, being generated in any sense: she is «the generative source of wholes and the principial [archêgon] cause of all things» (142.34). Note here the technical term 'source', pêgê, with its complementary 'principle', archê, in addition to the more subtle complementarity of 'whole' and 'all', corresponding respectively to the second and third intelligible triads. The second intellective father is the "generative cause of all the Gods" (142.8-9), precisely insofar as they are 'wholes', i.e., treated as if they are beings, which are necessarily determined by mereological structures. By virtue of the second intellective father, this implies an element of narrative sequence: "That which does not possess at once its whole essence or activity in unity is called 'generated'... all motion subsists according to the part and is not whole at once» (IT I, 277.27-33). Mythically, Rhea is indeed a bountiful mother; but she is "generative cause of all the Gods», with its explicit totality, from this intellective causality she operates. The third intellective father is the demiurge, much of whose activity must be taken up in an account of the psychogonic work involved in the procession of the 
hypercosmic Gods. I have spoken already of the demiurge's relation to the paradigm; what remains is the role of the third intellective father in completing the operation begun by the first. The intellective order is grounded in its third moment, in its perfection or telos, as the intelligible is grounded in its first or radical moment and the intelligible-intellective in its central or sustaining moment. The significance of the intellective procession lies accordingly in the demiurgic articulation of all that has come before, which he does by positioning himself in relation to it. If the first intellective father is a self-thinking deity, and the second a self-moving deity, then the third is a self-relating deity under the four-fold rubric of the determinations of identity and difference: identity-with-self, identity-with-the-other, difference-from-the-other, and difference-from-self.

The last of these belongs, as I have indicated, to the diacritical monad, while the third belongs to the third father's guardian or immaculate monad. Hence the function most proper to the demiurge is identification, underscoring that the sense of the entire divine procession is not the multiplication of an abstract unity, or differentiation within a totalizing substantial unity, but rather the emergence of community from concrete diversity. Prior to identity and difference, there is self and other: «From where does Parmenides say that this power [of difference, heterotês] come to him [the demiurge]? From the in-self and the in-other. For these [determinations] are in the first father unifically [hênomenôs], differentially [diakekrimenôs] in the third; there, determinacy [diakrisis] presubsisted causally, while in the demiurge it shines forth and reveals its proper power» ( $P T \mathrm{~V} 39$. 147.2-7). Diakrisis manifests in the demiurge according to a dialectic in which «insofar as he [the demiurge] is in another, he is united to the intelligible of himself, but insofar he is in himself he is separated from it, because he has proceeded according to each of its [the intelligible's] classes» (147.15-19). The demiurge projects himself into the intelligible object like the first intellective father; but his being in himself is an identification with each formal moment (or 'class') produced by the elaboration of the intelligible object in its objectivity.

In this way, the demiurge transcends the disposition of in-self and in-other and establishes genuine identity and difference, and in doing so, makes the philosophical system possible. Hence the self identity of the henad, «the monadic and paternal characteristic» (144.14-15), presents the One in its self-identity, according to which we speak of 'the One Itself'. 'Characteristic', idiotês, refers here not merely to a particular characteristic, namely, the characteristic of being monadic and paternal, but rather to the monadic and paternal nature of the characteristic as such. For Proclus has established idiotês, the positivity of henadic individuality, prior to formal identity-and-difference (IP 1049.23-27; cf. IP 1190.27-1191.1). Identity and difference occur against a common field, and it is this which demiurgy, more than any other divine disposition, establishes through identity-with-the-other: «For the demiurge is present to all he produces and is the same in all things which he arranges, preestablishing in himself the generative 
essence $^{17}$ of wholes» (144.25-7), that is, of beings as formal natures. Beings in this way participate the demiurge and to that extent «he is the same with them» (145.24).

The demiurge's difference-from-other, the immaculate/guardian function associated with him, on the other hand, establishes the demiurge as «unparticipated by other things" (146.2). Typically the condition of 'unparticipated', amethektos, is not associated with henads; the latter is thought of as a prerogative of the One Itself, and derivatively a property of the 'unparticipated' ontic hypostases that participate the various classes of Gods (ET props. 161-5). But to be 'unparticipated' is a property of «real Being», to ontôs on, which is simply the being that is «attached to the Gods» (ET prop. 161). Thus we may say that in the operations of the demiurge, Being has truly been produced with the appearance of the 'unparticipated' One as a property of the henad.

Finally, in differing from himself, a function vested in the diacritical monad, but which Proclus treats as a virtual part of the suite of demiurgic powers, the demiurge lends himself to the grand narrative of theogony. Hence, e.g., Zeus reappears in the hypercosmic order, where he divides the cosmic sovereignty with his brothers Poseidon and Hades, after operating as sole cosmic sovereign on the intellective plane ( $P T$ VI 8, pp. 34-42). Such divisions of divine persons are often treated by moderns as mere hermeneutical exigency; but that inconsistent narratives may apply to one and the same individual is essential to the nature of Being.

\section{CONCLUSION}

The determinations necessary for philosophy arise, therefore, out of narrative determinacy, and to this extent, from determinate narratives. What is the status, therefore, of the universality achieved? It is clear that no final 'demythologization' can occur, to the extent that revealed myth is inseparable from particular supra-essential individuals. To the extent, however, that the intellective structures derive from general characteristics of narrativity, they do not depend on any particular narrative, just as the intelligible structures, deriving from general characteristics of henadic individuality, did not depend on the analysis of this or that particular henad. But in neither case may we say that the formal is wholly independent of the existential. For Proclus, the exegesis of Plato can be no more independent of Hellenic theology than it can be of Plato's text; these are not 'material' determinations of a doctrine sufficient in its formality.

\footnotetext{
${ }^{17}$ Rejecting the unnecessary emendation of ousian to aitian-were it the latter, there would be no need to specify that the demiurge has preestablished it in himself, a God being prior to ousia (substance or essence), while the exercise of ultimate causality is the proper station of the Gods.
} 
More broadly, only the universality in the aims of the Gods of all peoples, a function of their universal goodness, allows one to predict some common result in the philosophical exegesis of discrete theologies. It would seem that the purpose of a text such as the Elements of Theology is to adumbrate such a general theology; it contains no references to factical theologies or even to Plato's texts. But its generality makes it not the most independent, but the most dependent of texts. In a way, it is paradoxical for Proclus to speak of a general theology, when it is the primacy of individuality for Platonism ${ }^{18}$ that makes Plato's theology necessarily Hellenic theology. Thus, at one typical moment, he urges us to turn «from the indefinite [aoristou] and common [koinês] doctrine concerning these Gods» to «the Hellenic tradition [phêmen] concerning them», with which he firmly associates Plato, who «follows the theologians of the Greeks as far as to the very names [of the Gods]» ( $P T \mathrm{~V}$ 35. 127.8-12). The procession of Being begins from the divine domain marked by proper names and particular languages, reaches through divine agency the domain of the formal, which is universal and hence indefinite, and then beyond to a lower particularity, such as ours, formally mediated in one respect, but possessing something proper to the divine as well in our unique agency, and the uniqueness of our traditions. This uniqueness does not prevent translation, any more than our own uniqueness preserves us from moral evaluation; but translation and evaluation alike would lose their point were they to proceed to eliminate their founding alterities.

Edward. P. Butler epb223@gmail.com

${ }^{18}$ "All those who have ever treated of theology have called 'Gods' whatever is primary kata physin, and said that the science of theology concerns these things» (PT I 3. 12.11-13). 


\section{BIBLIOGRAPHY}

BUTLER. E. P. (2005), The Theological Interpretation of Myth, "The Pomegranate: The International Journal of Pagan Studies", 7, 27-41.

- (2008), Polycentric Polytheism and the Philosophy of Religion, "The Pomegranate: The International Journal of Pagan Studies", 10, 207-229.

- (2008a), The Intelligible Gods in the Platonic Theology of Proclus, "Méthexis" 21, 131-143

- (2010), The Second Intelligible Triad and the Intelligible-Intellective Gods, "Méthexis", 23,137-157.

DIEHL, E., (1903-6) (ed.), Proclus Diadochus In Platonis Timaeum Commentaria, 3 vols., Leipzig, Teubner.

DODDS, E. R. (1963) (ed.), Proclus: The Elements of Theology, Oxford, Clarendon Press.

DUVICK, B. (2007) (ed.), Proclus: On Plato's Cratylus, London, Duckworth.

MORrow, G. R. - Dillon, M. (1987), (ed.) Proclus' Commentary on Plato's

Parmenides, Princeton, Princeton University Press.

PASQUali, G. (1908), Proclus Diadochus In Platonis Cratylum Commentaria Leipzig, Teubner.

SAFFREY, D. - WeSterinK, L. G. (2003) (éd.), Proclus: Théologie Platonicienne, ed. 6 vols., Paris, Les Belles Lettres. 